\title{
MONITORING AND PRESERVATION OF THE KYIV PECHERSK LAVRA CAVES
}

\author{
R. Shults ${ }^{1 *}$, M. Bilous ${ }^{2}$, V. Kovtun ${ }^{2}$ \\ ${ }^{1}$ GIS and Land Management Faculty, Kyiv National University of Construction and Architecture, Povitroflotskij Ave, Kyiv, Ukraine \\ - shultsrv@gmail.com \\ 2 Joint stock company “Kyivmetrobud”, 4 Kablukova str., Kyiv, 03065, Ukraine, ukrgeoinstrument@ gmail.com
}

Commission V, WG V/7

KEY WORDS: Terrestrial Laser Scanning, 3D Modeling, Kyiv Pechersk Lavra Caves, GIS, TIN

\begin{abstract}
:
The Kyiv Pechersk Lavra is a unique monastery complex included in the UNESCO World Heritage List. The first mentions of the caves in the chronicles date back to the year 1051. The idea of creating a 3D model of Lavra's caves was suggested by the Kiev Pechersk Lavra coenobites with the aim to attract public attention to the problem of preserving the Lavra Caves for future generations. It consists of an above-ground part (a complex of religious buildings) and an underground part (caves). The caves form a system of underground corridors subdivided into several parts - the Near Caves, the Far Caves, and the Varangian Caves. Today the caves are in an emergency state and need urgent restoration. Results presented in the paper comprise all steps of the 3D model of the Kyiv Pechersk Lavra caves creation. At the first step, a spatial underground geodetic network for scans georeferencing was created. Totally over 60 stations with quite short distances from $2 \mathrm{~m}$ up to $15 \mathrm{~m}$, with many open traverses were measured. Terrestrial laser scanning for over than $450 \mathrm{~m}$ tunnels and entrance structures has been performed. At the last step, data processing and modelling have been done with a result in the form of plans, cross-sections and TIN model of the whole complex. The paper devoted to features of those works and prospective applications of the results.
\end{abstract}

\section{INTRODUCTION}

The ancient Kyiv is over 1,500 years old. The first mention about Kyiv in historical chronicles dates back to 862 A.D. It was the capital of powerful state Kyiv Rus, and since that time people call it "The Heart of Rus" and "The Mother of Rus Cities". Among many ancient objects, Kyiv Pechersk Lavra takes a prominent place as the centre of the East Orthodox culture. The first mentions of the caves in the chronicles date back to the year 1051. It consists of an above-ground part (a complex of religious buildings) and an underground part (caves). The caves form a system of underground corridors subdivided into several sections - the Near Caves, the Far Caves, and the Varangian Caves. Monks lived there at first, but later the place was used for burying deceased monastery settlers and caves became a place for imperishable relics of saints.

Inhabitants of the Kyiv Pechersk Lavra suggested the creation of a 3D model of the Lavra caves. The need for a detailed map of the dungeons arose in 2005 when a crater was formed as a result of the collapse in one of the Far Caves. During the restoration works, it turned out that the existing plans for caves labyrinths dated 1974 have serious errors. Using these plans can lead to error in position in 1-2 meters at least.

In the modern city, the task of monitoring the architectural monuments is vital. As a part of the implementation of the Resolution of the Cabinet of Ministers of Ukraine No. 1330 "On Approval of the Integrated Program for the Certification of Cultural Heritage Objects for 2003-2010" and the Law of Ukraine No. 1692-IV "On Approval of the National Program for the Conservation and Use of Cultural Heritage Objects for 20042010 years", with the support of the enterprise "Ukrgeodezmark"
(Kyiv), a project on scanning and creation of 3D model of the complex of caves of the Kyiv Pechersk Lavra was implemented. Of particular importance this project has because the climate conditions and location in the center of the urban area, with the presence of underground caves, creates conditions for the widespread development of peculiar deep landslides in the area. The key technology for that project was chosen terrestrial laser scanning (TLS). TLS is designed to build a 3D model for research and prevent the development of destructive processes on the site, as well as for accurate documentation of the shape and spatial position of the object. There are many examples of TLS application for such or similar tasks. Since TLS technology had been invented a lot of works and studies have been done, among them it would be pointed out (Fryer, et al. 2005, Ruther, et al. 2009, Lerma, et al. 2009, Gonzales-Aguilera, et al. 2009, Grussenmeyer, et al. 2010, Cosso, et al. 2014, Gallay, et al. 2015). Many authors consider TLS as complimentary technology to close-range photogrammetry or vice versa (Fryer et al. 2005, Alshawabkeh, 2006, Rodríguez-Gonzálvez, et al. 2015, Majid, et al. 2017, Clini, et al. 2019, Ebolese, et al. 2019). However, that project is based just on TLS data with a photo capturing for documentation. There is no need to list all the pros and cons of TLS, insofar as it has been considered in many papers. Our task is to show how TLS works in such extreme conditions and to demonstrate a workflow with peculiar features. According to the research work, the following workflow was proposed.

1. object study, historical search, recognition and selection of points for installing the scanner;

2. placement the special targets in the areas of the ceiling on the interior surfaces of the caves;

\footnotetext{
* Corresponding author
} 
3. underground geodetic network creation;

4. determination of reference points and scanner stations coordinates;

5. determination of each scan station parameters;

6. terrestrial laser scanning;

7. coordinates transformation of point clouds into a single point cloud;

8. measurement accuracy control;

9. construction of spatial model (point cloud, TIN, solid model);

10. creation of drawings.

Let us consider and discuss all of those stages step by step.

\section{THE KYIV PECHERSK LAVRA CAVES. A BRIEF} HISTORICAL BACKGROUND

Kyiv Pechersk Lavra (Fig. 1) is the oldest Orthodox monastery, the cradle of monasticism in Russ and the stronghold of the Orthodox faith. The history of the monastery begins with 1051 , since the reign of Yaroslav the Wise. The founders of the monastery were monks Anthony and Theodosius, one of his first students. Prince Svyatoslav II Yaroslavich presented an area above the caves to the monastery, where later beautiful stone temples, cells, fortress towers, and other buildings have grown up decorated with paintings. In the XII century, the monastery received the status of "Lavra" which means the large main monastery.

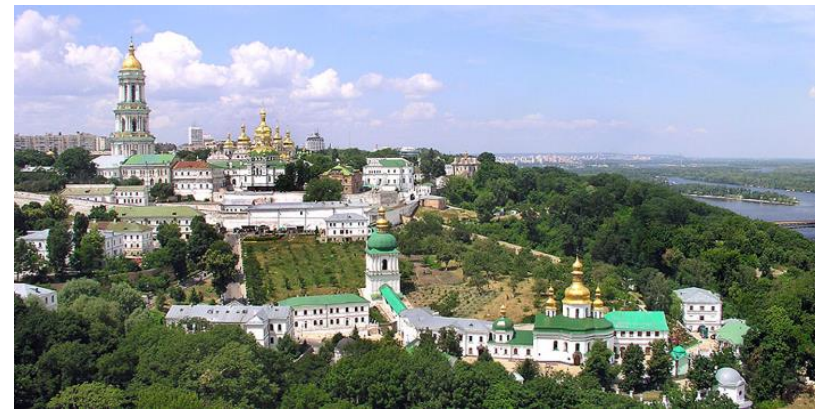

Fig. 1. Kyiv Pechersk Lavra complex

The Pechersk monastery was playing a significant role in the unification of the Eastern Slavic lands, being a spiritual, social, cultural and educational center, and deserved fame not only in Ukraine, but also in Russia, Poland, Armenia, Byzantium, and other countries. The complexes of the Near and Far Caves are the main attractions of the Lavra. Since 1990, the Kyiv Pechersk Lavra was included in the UNESCO World Heritage List.

There is only one way to save and protect this unique object for future generations, it is a creation of a complex 3D model for the restoration and monitoring.

\section{UNDERGROUND GEODETIC NETWORK}

Before terrestrial laser scanning of the caves, the underground geodetic network has to be created. For scanning, the underground geodetic network has been used in the form of traverses and closed polygons laid out along the main corridors of the nearby caves. Heights were determined by trigonometric leveling. This network (Fig. 2) fixed a permanent system of coordinates and heights for further surveying and geodetic observations.

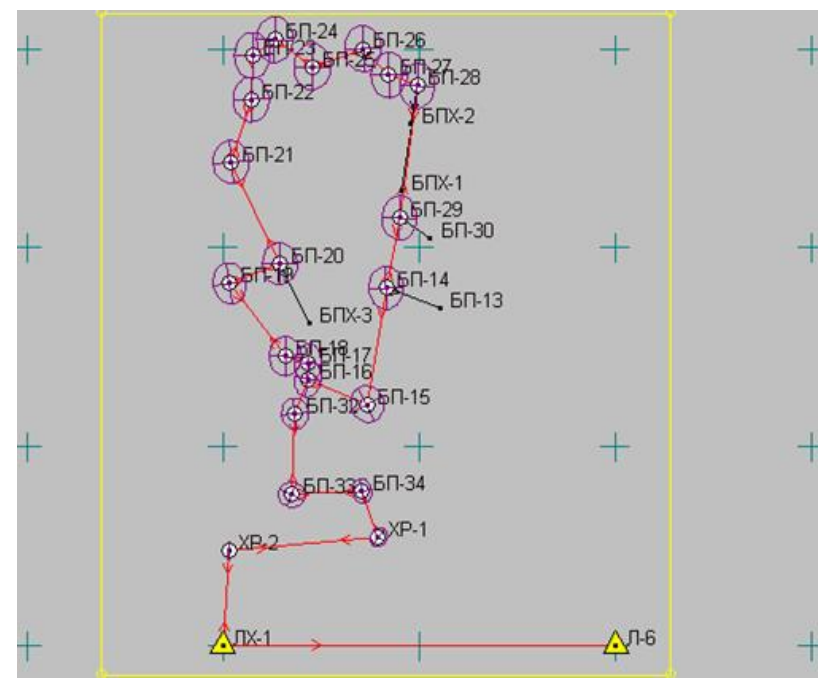

Fig. 2. Scheme of the underground geodetic network

Point of beginning for the coordinate system was chosen arbitrarily, but an appropriate connection with the above-ground geodetic network was established. It was done just for control. Topcon GPT-6001C total station (Fig. 3) was used to create the underground geodetic network and the referencing of scanning targets. All angular measurements were completed with at least four repetitions, the length of the lines measured in the forward and reverse directions, with an accounting of all the necessary corrections.

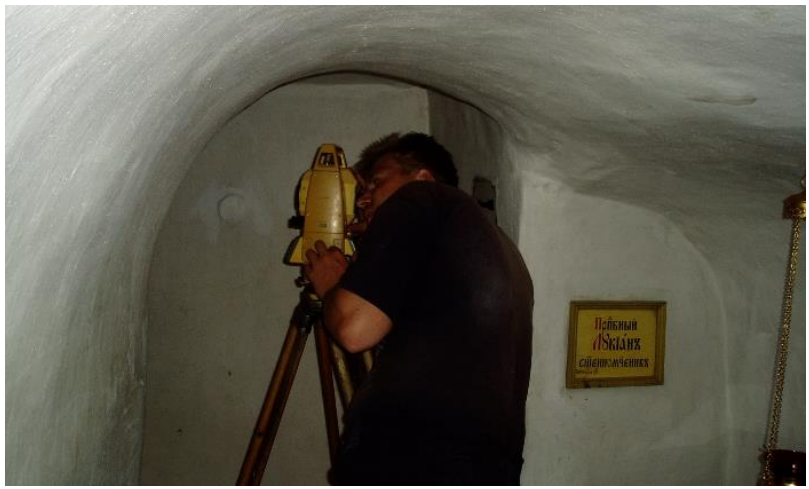

Fig. 3. Performance of geodetic measurements in caves

For the georeferencing of the scanning data, the "free station" method was used (Fig. 4.).

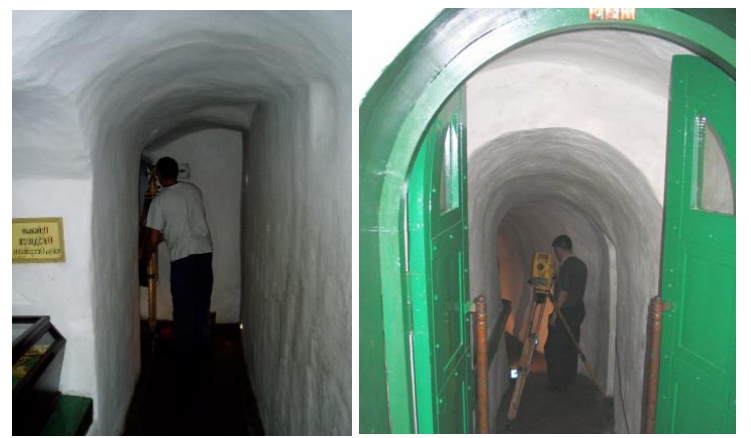

Fig. 4. Scanning stations georeferencing by free station method 
Simultaneously with the laying of traverses, determination of the points heights by the method of two-way trigonometric leveling was carried out, which corresponds to the accuracy of the leveling $10 \mathrm{~mm}$ for $1 \mathrm{~km}$.

In general, in a weak place of horizontal network RMS did not exceed $4 \mathrm{~mm}$, and for leveling network $-3 \mathrm{~mm}$.

\section{TERRESTRIAL LASER SCANNING}

The primary goals of the project were to create a TIN-surface of the object, to obtain a topographic plan of 1:500 scale in the local coordinate system, to build profiles and sections of corridors and cave rooms. Technical specifications for the production of these works were developed by specialists of the subsidiary enterprise "Ukrgeodezmark". Laser scanning work was carried out with a Leica ScanStation.

Due to the huge attendance of the caves (excursions, pilgrims), scanning was performed at night. The total length of the caves for scanning was about 450 meters.

From each scan station, at least two orientation targets were scanned (Fig. 5).

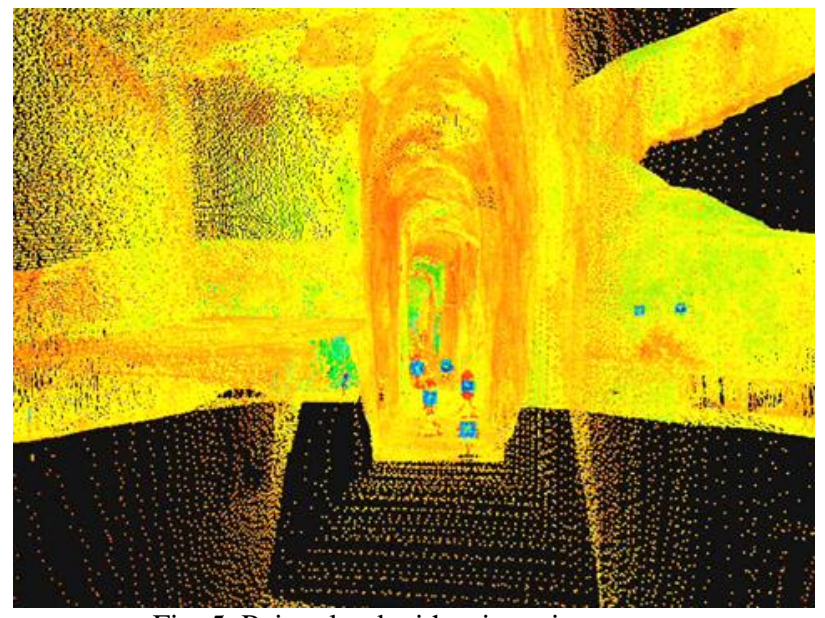

Fig. 5. Point cloud with orientation targets

A total station in reflectorless mode measured the coordinates of these targets. The mini-prisms and targets on tripods were used as orientation targets too (Fig. 6).

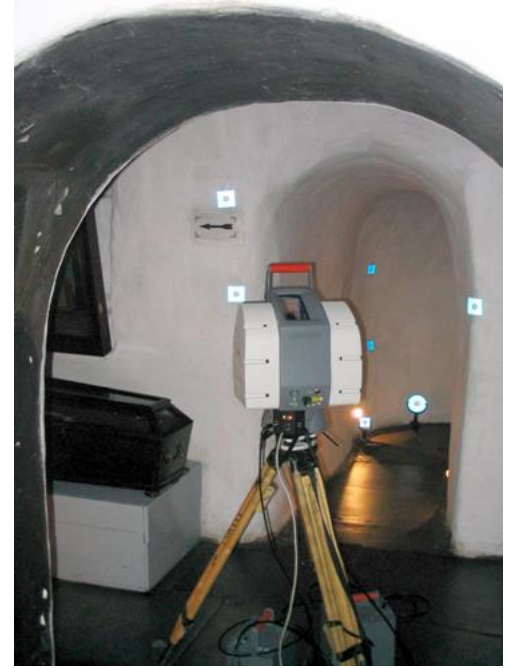

Fig. 6. Leica ScanStation and different orientation targets
In a matter of fact, due to narrow corridors in the caves, the small rooms of churches and auxiliary halls, and a quite complicated configuration, the works were too complicated. Therefore, the method of scanning with the help of scripts (specially written in "Cyclone" script macros for each scan area) was chosen. This technique allowed to get the same resolution when scanning objects at different distances from the scanner and significantly reduced the overall scanning time (state-of-the-art scanners have such embedded option). At the same time, the final point cloud density remained unchanged. Also, this method allows for reducing the amount of received information. When working in similar conditions, e.g., in corridors or churches, an already recorded set of macro commands was used, which also made it possible to reduce the time of work.

Technologically the most problematic for the scanning turned out to be the Varangian caves. In some places, the distance between adjacent scan stations was no more than 1.5-2 m, and the height of the cave arches above the floor was about one meter. The constant temperature in the Varangian caves lasts all year round from $+8{ }^{\circ} \mathrm{C}$ to $+12{ }^{\circ} \mathrm{C}$, and the humidity reaches $100 \%$. The Varangian caves are untreated excavations in the ground (sandstone), and sand has abounded almost everywhere. For the normal operation of the laser scanner, additional steps had to be applied. In particular, to avoid condensate residues, after reaching the surface, the scanner was being turned on again and worked for some time.

\section{DATA PROCESSING AND MODELING}

\subsection{Point Clouds}

More than 130 scans of the visited part of the Far Caves and about 30 scans of the Varangian caves, closed for visiting have been performed (Fig. 7 and Fig. 8).

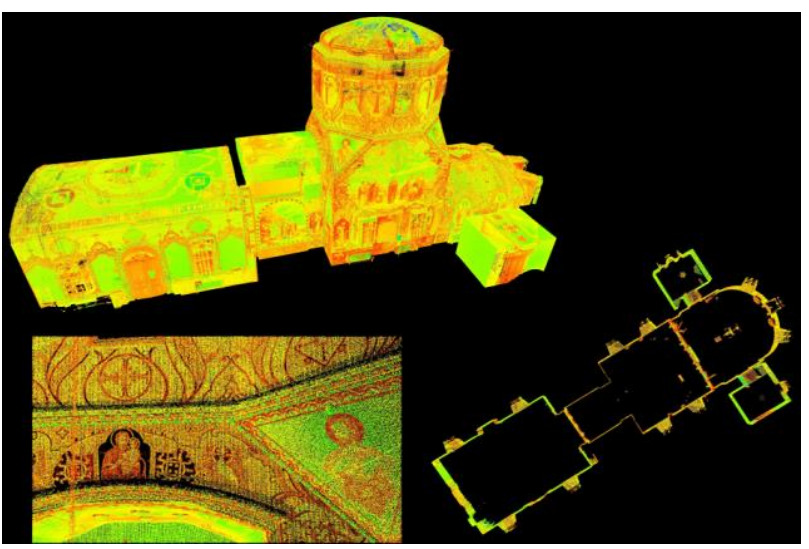

Fig. 7. Point cloud of the main entrance to the caves

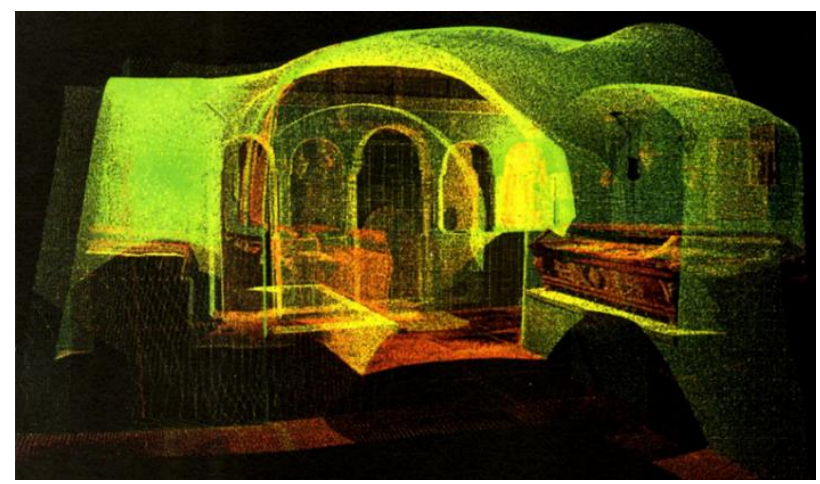

Fig. 8. A sample of point cloud after filtering 
Laser scanning data were processed in the Cyclone 5.6 software. The whole point cloud 3D model was created by the orientation of particular models. Before orientation of point clouds in one model, the filtering and smoothing have been done. After preliminary scans referencing by orientation targets, the final RMS of the relative scans referencing did not exceed $4 \mathrm{~mm}$. Determination of the coordinates of objects relative to the points of the underground geodetic network did not exceed $8 \mathrm{~mm}$.

\subsection{TIN and solid model generating}

By the whole 3D point cloud, the TIN model has been generated. As a based model, TIN with a step $50 \mathrm{~mm}$ has been created (Fig. 9).

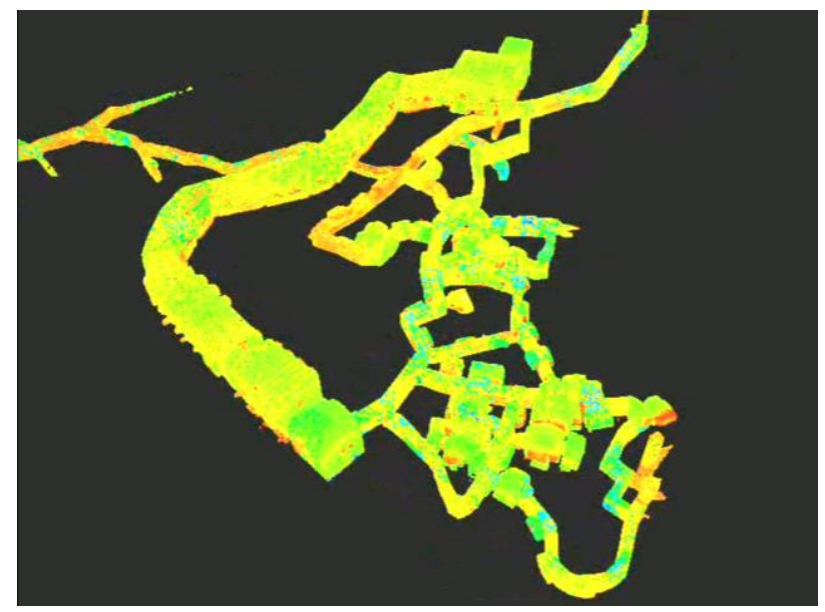

Fig. 9. TIN 3D model of the Kyiv Pechersk Lavra caves

In specific places with complicated surface geometry, TIN was created with a step equals to $25 \mathrm{~mm}$ (Fig. 10).

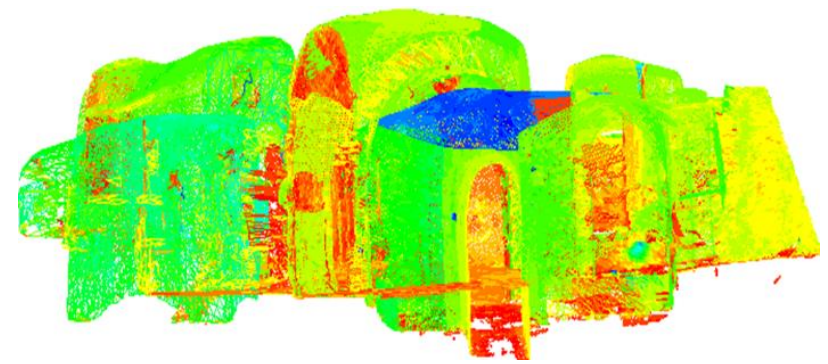

Fig. 10. Sample TIN model with a step equals to $25 \mathrm{~mm}$

The final step in the modelling is the creation of a solid model of the caves complex (Fig. 11 and Fig. 12).

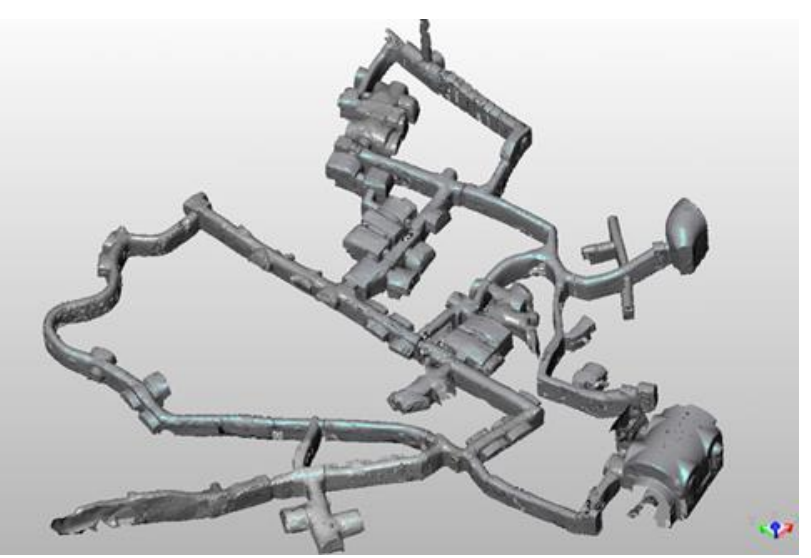

Fig. 11. Solid model of the Kyiv Pechersk Lavra caves

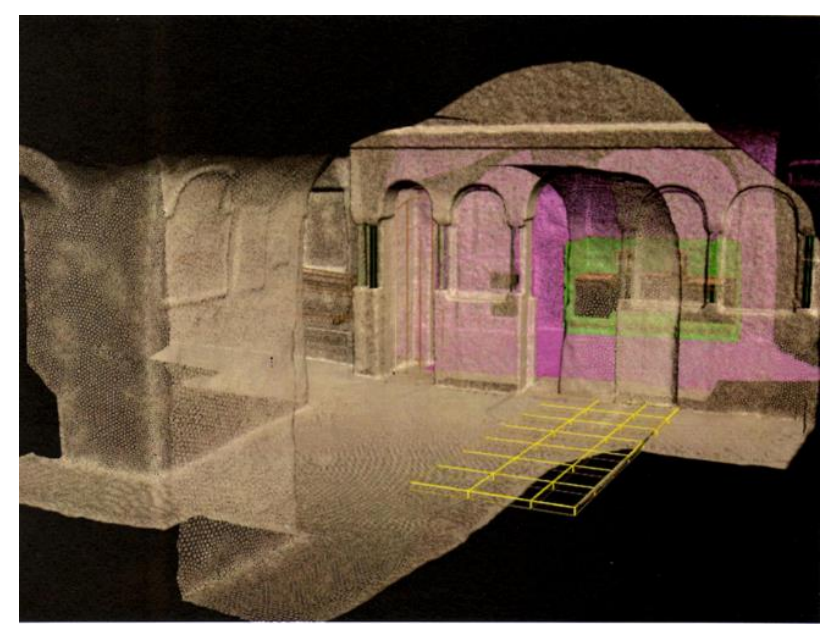

Fig. 12. A sample of the solid model of the Kyiv Pechersk Lavra caves

Having modelled the point cloud, we have an opportunity to create plans and different cross-sections of that model.

\subsection{Plans and Sections}

The solid model allows recognizing and drawing up objects of interest. For these goals, the RealWorks Survey was used. Thus, a 3D digital model was created and 1:500 plan (Fig. 13) was constructed that could be used for further monitoring.

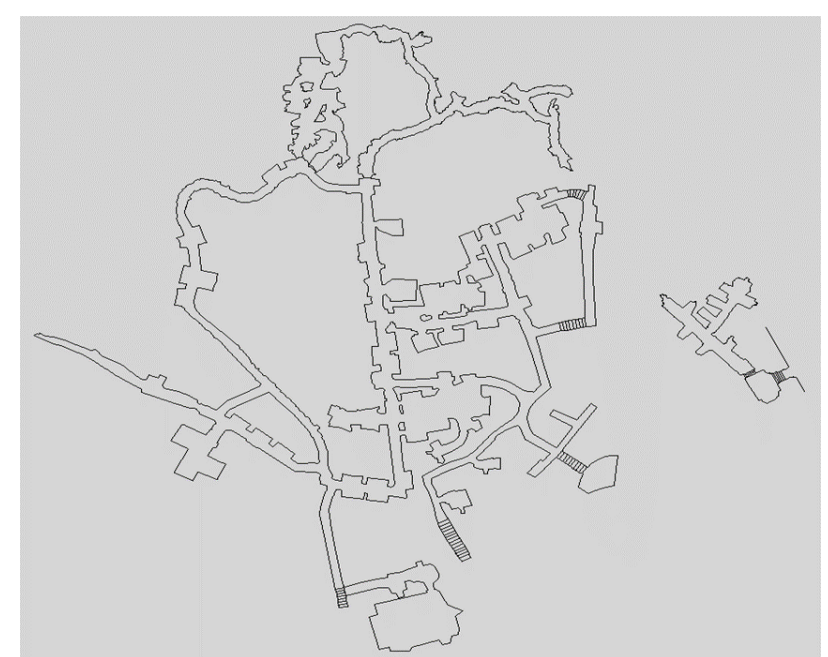

Fig. 13. Horizontal plan of the Kyiv Pechersk Lavra caves

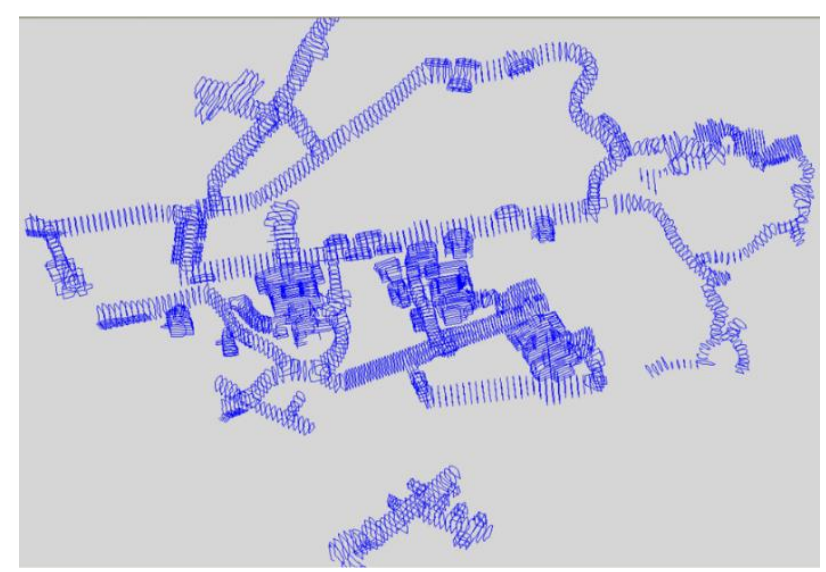

Fig. 14. Vertical cross-sections of the Kyiv Pechersk Lavra caves 
Except of plans, another useful information can be derived from the solid model, for instance, vertical cross-sections with different steps (Fig. 14) or plans with heights at specified points (Fig. 15).

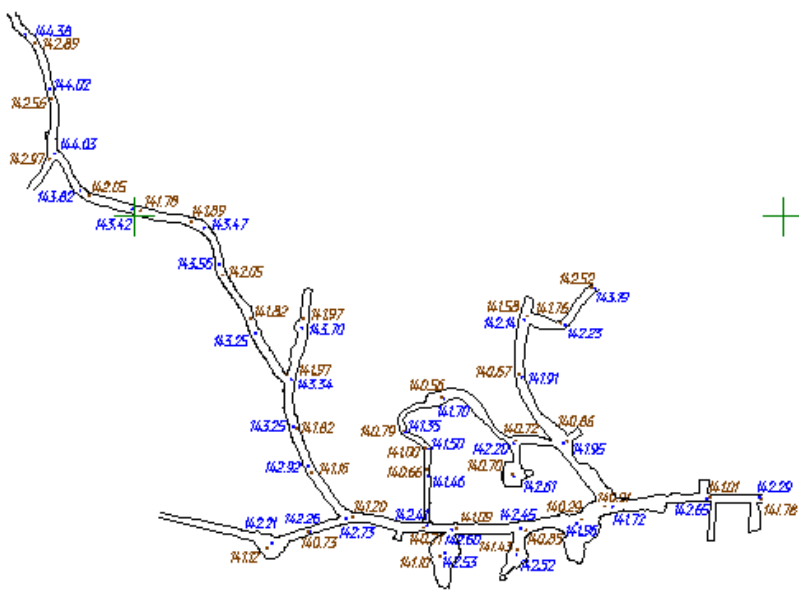

Fig. 15. A sample of caves plan with heights

\section{CONCLUSIONS}

The obtained TLS data, besides the above-mentioned purpose, play an important role in preserving the historical and cultural heritage and in the future can also serve as the basis for creating a 3D BIM of the cave complex, as it is suggested in (Banfi, et al. 2017, Dore, et al. 2017). Having such unique data, obtained with the help of the TLS for the Kyiv Pechersk Lavra caves, the creation of its own 3D geographical information system (3D GIS) becomes a reality. In this case, the TLS data several times simplifies the task of creating such a 3D GIS. Initially, it is possible to create a photo-realistic 3D GIS caves complex with interactive visualization. Such a 3D GIS may include the following components and functions:

- creation of a 3D photo-realistic model, including the following elements: a photo-realistic plan of the surrounding territory (the above-ground part, i.e. the entrance and the exit, nearby buildings, other elements of the landscape); maps of the corresponding area of Kyiv and the Lavra itself; DEM with the complex of caves underneath;

- creation of an information database, including a database of the internal contents of the caves (raki, altars of churches, icons, images, lamps, icon lamps, candlesticks, etc.), multimedia information, photos, text documents;

- development of an interactive 3D GIS interface with multiparameter information retrieval and the ability to present results on a 3D model;

- project development for the creation of various thematic presentation videos based on the interactive models. The project will allow going thru the caves, assess the scale of the territory they occupy, create sound and voice background with information notes.

In the future, when creating a 3D GIS of the Kyiv Pechersk Lavra, the previously developed 3D GIS complex of the caves would be its integral part. The presence of such a 3D GIS would allow with maximum accuracy, speed, and at any time to reproduce the unique architecture of the Lavra structures, its internal content, to make the design during the construction or reconstruction of objects, for instance:

- to plan the reconstruction and development of the territory in terms of architecture, social and engineering infrastructure, engineering-geological processes, ecology, recreation, efficient land use, etc.;

- to evaluate the project from the point of view of a single architectural style in the design of new buildings, positioning and compatibility of structures within the existing buildings, existing and prospective infrastructure facilities and landscape;

- to carry out, through the interactive visualization, monitoring of the layout of the buildings and engineering communications (underground part and all types of structures);

- to make further control and final development of facade solutions, internal planning, landscape design, etc.

In conclusion, it has to be emphasized that obtained data of $3 \mathrm{D}$ laser scanning can serve as a unique material for creating a historical geographic information system (HGIS) of the caves complex and HGIS of the Kyiv Pechersk Lavra. 3D GIS/HGIS created in the future will give an opportunity to many pilgrims who are not able to come to Kyiv virtually go through the holy places of the monastery and worship the Christian wonders with the help of new technologies.

\section{REFERENCES}

Alshawabkeh, Y., 2006. Integration of Laser Scanning and Photogrammetry for Heritage Documentation. Institut fur Photogrammetrie der Universitat Stuttgart, Doktor-Ingenieurs (Dr.-Ing.), 98 p.

Banfi, F., Barazzetti, L., Previtali, M., Roncoroni, F., 2017. Historic BIM: A new repository for structural health monitoring, 2017 GEOMATICS \& RESTORATION - Conservation of Cultural Heritage in the Digital Era, In Proc. ISPRS Arch. Photogramm. Remote Sens. Spatial Inf. Sci., Volume XLII-5/W1. pp. 269-274. https://doi.org/10.5194/isprs-archives-XLII-5-W1269-2017

Clini, P., Nespeca, R., Angeloni, R., Mammoli, R., 2019. The integrated survey of narrow spaces and underground architecture: The case study of Campana caves bas-reliefs, In Proc. ISPRS Arch. Photogramm. Remote Sens. Spatial Inf. Sci., Volume XLII2/W9. pp. 277-282. https://doi.org/10.5194/isprs-archives-XLII2-W9-277-2019

Cosso, T., Ferrando, I., Orlando, A., 2014. Surveying and mapping a cave using 3D laser scanner: the open challenge with free and open source software, In Proc. ISPRS Arch. Photogramm. Remote Sens. Spatial Inf. Sci., Volume XL-5. pp. 181-186. https://doi.org/:10.5194/isprsarchives-XL-5-181-2014

Dore, C., Murphy, M., 2017. Current state of the art historic building information modelling, 26th International CIPA Symposium, In Proc. ISPRS Arch. Photogramm. Remote Sens. Spatial Inf. Sci., Volume XLII-2/W5. pp. 185-192. https://doi.org/10.5194/isprs-archives-XLII-2-W5-185-2017

Ebolese, D., Lo Brutto, M., Dardanelli, G., 2019. The integrated 3D survey for underground archaeological environment, In Proc. ISPRS Arch. Photogramm. Remote Sens. Spatial Inf. Sci., 
Volume XLII-2/W9. pp. 311-317. https://doi.org/10.5194/isprsarchives-XLII-2-W9-311-2019

Fryer, J.G., Chandler, J.H., El-Hakim, S.F., 2005. Recording and modelling an aboriginal cave painting: with or without laser scanning?, 3D-ARCH 2005: Virtual Reconstruction and Visualization of Complex Architectures, In Proc. ISPRS Arch. Photogramm. Remote Sens. Spatial Inf. Sci., Volume XXXVI5/W17. $8 \mathrm{p}$.

Gallay, M., Kaňuk, J., Hochmuth, Z., Meneely, J.D., Hofierka, J., Sedlák, V., 2015. Large-scale and high-resolution 3-D cave mapping by terrestrial laser scanning: a case study of the Domica Cave, Slovakia. International Journal of Speleology, 44(3), pp. 277-291. http://dx.doi.org/10.5038/1827-806X.44.3.6

Gonzales-Aguilera, D., Munoz-Nieto,A., Gomez-Lahoz, J., Herrero-Pascual, J., Guitirrez-Alonso, G., 2009. 3D Digital surveying and modelling of cave geometry: Application to Paleolithic Rock art. Sensors 9, pp. 1108-1127.

Grussenmeyer, P., Landes, T., Alby, E., Carozza, E., 2010. High resolution $3 \mathrm{D}$ recording and modelling of the bronze age cave "Les Fraux" in Perigord (France), In Proc. ISPRS Arch. Photogramm. Remote Sens. Spatial Inf. Sci., Vol. XXXVIII, Part 5, pp. 262-267. https://doi.org/ 10.5194/isprsarchives-XL-5-W4$17-2015$

Lerma, J., Navarro, S., Cabrelles, M., Villaverde, V., 2009. Terrestrial laser scanning and close range photogrammetry for 3D archaeological documentation: the Upper Palaeolithic Cave of Parpalló as a case study, Journal of Archaeological Science, Volume 37, Issue 3, pp. 499-507.

Majid, Z., Ariff, M.F.M., Idris, K.M., Yusoff, A.R., Idris, K.M., Aspuri, A., Abbas, M.A., Zainuddin, K., Ghani, A.R.A, 2017. Three-dimensional mapping of an ancient cave paintings using close-range photogrammetry and terrestrial laser scanning technologies, 3D Virtual Reconstruction and Visualization of Complex Architectures, In Proc. ISPRS Arch. Photogramm. Remote Sens. Spatial Inf. Sci., Volume XL-5/W4. pp. 453-457. https://doi.org/10.5194/isprs-archives-XLII-2-W3-453-2017

Rodríguez-Gonzálvez, P., Nocerino, E., Menna, F., Minto, S., Remondino, F., 2015. 3D surveying \& modeling of underground passages in WWI fortifications, 3D Virtual Reconstruction and Visualization of Complex Architectures, In Proc. ISPRS Arch. Photogramm. Remote Sens. Spatial Inf. Sci., Volume XL-5/W4. pp. 17-24. https://doi.org/ 10.5194/isprsarchives-XL-5-W4-172015

Ruther, H., Chazan, M., Schroeder, R., Neeser, R., Held, C., Walker, S.J., Matmon, A., Horwitz, L.K., 2009. Laser scanning for conservation and research of African cultural heritage sites: the case study of Wonderwerk Cave, South Africa. Journal of Archaeological Science, 36, pp. 1847-1856 http://dx.doi.org/10.1016/j.jas.2009.04.012 